\title{
Teaching NeuroImages: Brain MRI and DaT- SPECT imaging in adult GM1 gangliosidosis
}

Antonio Marangi, MD, Matteo Tagliapietra, MD, Virginia Vicenzi, MD, Isabella Pasquin, MD, and Alessandro Salviati, MD, PhD

Neurology ${ }^{\circledR}$ 2018;91:e187-e188. doi:10.1212/WNL.0000000000005775
Correspondence

Dr. Marangi

marangi2010@libero.it

Figure MRI and DaT-SCAN SPECT findings in the adult GM1 gangliosidosis patient

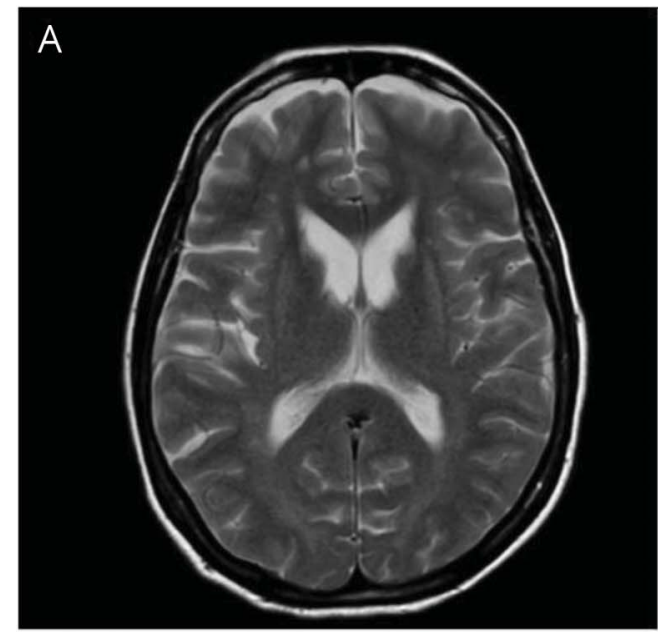

\section{B}



(A, B) Axial T2-weighted imaging and fluid-attenuated inversion recovery images show increased signal in the putamina. (C) DaT-SPECT demonstrates decreased radiotracer uptake in the bilateral basal ganglia suggestive of nigrostriatal dopaminergic dysfunction. More diffuse involvement of putamen and caudate nucleus can be noted on the left side.
A 58-year-old woman with genetically confirmed adult GM1 gangliosidosis (aGM1-g) presented with generalized dystonia that was later followed by akinetic-rigid parkinsonism. Brain MRI revealed hyperintensities in the bilateral putamen typically observed in this disease ${ }^{1}$ (figure, A and B), while DaT-SPECT ( ${ }^{123}$ I-Ioflupane) showed decreased radiotracer uptake in both basal ganglia, more evident on the left side (figure, C). Selective involvement of the basal ganglia in aGM1-g is thought to be related to a higher turnover of GM1 ganglioside in this region. ${ }^{2}$ Our report suggests a presynaptic pattern of dopaminergic dysfunction in this disease.

\section{MORE ONLINE}

$\rightarrow$ Teaching slides

links.lww.com/WNL/A570

\section{Author contributions}

Dr. Antonio Marangi: case report organization, analysis of data, draft of manuscript. Dr. Matteo Tagliapietra: analysis of data, manuscript review and critique. Dr. Virginia

From the Department of Neurosciences, Biomedicine and Movement Sciences (A.M., M.T., V.V., A.S.), and Interdisciplinary Group for Hereditary Metabolic Diseases (GIMME) (A.S.), University of Verona; and Department of Nuclear Medicine (I.P.), Azienda Ospedaliera Universitaria Integrata, Verona, Italy.

Go to Neurology.org/N for full disclosures. Funding information and disclosures deemed relevant by the authors, if any, are provided at the end of the article. 
Vicenzi: manuscript review and critique. Dr. Isabella Pasquin: analysis of instrumental images, manuscript review and critique. Dr. Alessandro Salviati: case report conception and organization, analysis of data, manuscript review and critique.

\section{Study funding}

No targeted funding reported.

\section{Disclosure}

The authors report no disclosures relevant to the manuscript. Go to Neurology.org/N for full disclosures.

\section{References}

1. Roze E, Paschke E, Lopez N, et al. Dystonia and parkinsonism in GM1 type 3 gangliosidosis. Mov Disord 2005;20:1366-1369.

2. Yoshida K, Ikeda S, Kawaguchi K, Yanagisawa N. Adult GM1 gangliosidosis: immunohistochemical and ultrastructural findings in an autopsy case. Neurology 1994;44:2376-2382. 


\title{
Neurology
}

\author{
Teaching NeuroImages: Brain MRI and DaT-SPECT imaging in adult GM1 \\ gangliosidosis \\ Antonio Marangi, Matteo Tagliapietra, Virginia Vicenzi, et al. \\ Neurology 2018;91;e187-e188 \\ DOI 10.1212/WNL.0000000000005775
}

\section{This information is current as of July 9, 2018}

\section{Updated Information \& Services}

References

Subspecialty Collections

Permissions \& Licensing

Reprints including high resolution figures, can be found at: http://n.neurology.org/content/91/2/e187.full

This article cites 2 articles, 1 of which you can access for free at: http://n.neurology.org/content/91/2/e187.full\#ref-list-1

This article, along with others on similar topics, appears in the following collection(s):

Basal ganglia

http://n.neurology.org/cgi/collection/basal_ganglia

Dystonia

http://n.neurology.org/cgi/collection/dystonia

Parkinson's disease/Parkinsonism

http://n.neurology.org/cgi/collection/parkinsons_disease_parkinsonism SPECT

http://n.neurology.org/cgi/collection/spect

Information about reproducing this article in parts (figures,tables) or in its entirety can be found online at:

http://www.neurology.org/about/about_the_journal\#permissions

Information about ordering reprints can be found online:

http://n.neurology.org/subscribers/advertise

Neurology ${ }^{\circledR}$ is the official journal of the American Academy of Neurology. Published continuously since 1951, it is now a weekly with 48 issues per year. Copyright (O) 2018 American Academy of Neurology. All rights reserved. Print ISSN: 0028-3878. Online ISSN: 1526-632X.



